\section{In vitro Effects of Muscodor albus and Three Volatile Components on Growth of Selected Postharvest Microorganisms}

\author{
Ali A. Ramin, ${ }^{1}$ P. Gordon Braun, Robert K. Prange, ${ }^{2}$ and John M. DeLong \\ Agriculture and Agri-Food Canada, Atlantic Food and Horticulture Research \\ Centre, 32 Main Street, Kentville, Nova Scotia, B4N 1J5 Canada
}

Additional index words. bacteria, biofumigation, disease control, fungi, organic volatiles

Abstract. Biofumigation by volatiles of Muscodor albus Worapong, Strobel \& W.M. Hess, an endophytic fungus, was investigated for the biological control of three postharvest fungi, Botrytis cinerea Pers., Penicillium expansum Link, and Sclerotinia sclerotiorum (Lib) de Bary, and three bacteria, Erwinia carotovora pv. carotovora (Jones) Bergey et al., Pseudomonas fluorescens Migula (isolate A7B), and Escherichia coli (strain K12). Bacteria and fungi on artificial media in petri dishes were exposed to volatiles produced by $M$. albus mycelium growing on rye seeds in sealed glass 4 -L jars with or without air circulation for up to 48 hours. The amount of dry $M$. albus-rye seed culture varied from 0.25 to $1.25 \mathrm{~g} \cdot \mathrm{L}^{-1}$ of jar volume. Fan circulation of volatiles in jars increased efficacy and $0.25 \mathrm{~g} \cdot \mathrm{L}^{-1}$ with fan circulation was sufficient to kill or suppress all fungi and bacteria after 24 and 48 hours, respectively. Two major volatiles of $M$. albus, isobutyric acid (IBA) and 2-methyl-1-butanol (MB), and one minor one, ethyl butyrate (EB), varied in their control of the same postharvest fungi and bacteria. Among the three fungi, IBA killed or suppressed $S$. sclerotiorum, $B$. cinerea, and $P$. expansum at 40,25 , and $45 \mu \mathrm{L} \cdot \mathrm{L}^{-1}$, respectively. MB killed or suppressed $S$. sclerotiorum, $B$. cinerea, and $P$. expansum at 75,100 , and 100 $\mu \mathbf{L} \cdot \mathbf{L}^{-1}$, respectively. EB was only able to kill $S$. sclerotiorum at $100 \mu \mathbf{L} \cdot \mathbf{L}^{-1}$. Among the three bacteria, IBA killed or suppressed $E$. coli (K12), E. carotovora pv. carotovora, and $P$. fluorescens at $5,12.5$, and $12.5 \mu \mathrm{L} \cdot \mathrm{L}^{-1}$, respectively. MB killed or suppressed $E$. coli $(\mathrm{K} 12)$, $E$. carotovora pv. carotovora, and $P$. fluorescens at 100,75 , and $100 \mu \mathrm{L}^{-1} \mathrm{~L}^{-1}$, respectively. EB did not control growth of the three bacteria. This study demonstrates the need for air circulation in M. albus, MB, and IBA treatments to optimize the efficacy of these potential postharvest agents of disease control.

Bacterial and fungal infections, which may occur at harvest, during handling, storage, transport and marketing, and after consumer purchase (Eckert and Ogawa, 1988), are a major cause of postharvest loss in horticultural crops Several fungicides and volatile chemicals are available for postharvest treatment of fruits and vegetables, but some of them have been removed from the market due to possible toxicological risks or insufficient efficacy (Adaskaveg et al., 2002). At the same time, there is a growing interest in finding and developing more natural means of controlling postharvest diseases (Ezra et al., 2004a; Mercier and Jiménez, 2004; Strobel et al., 2001).

An interesting candidate for biological control is Muscodor albus isolate 620 (Worapong et al., 2001) an endophytic fungus isolated from a cinnamon tree (Ezra et al., 2004b; Ezra and Strobel, 2003; Strobel et al., 2001). Muscodor albus inhibits and/or kills microorganisms by production of a number of volatiles, mainly alcohols, acids, and es-

Received for publication 2 June 2005. Accepted for publication $26 \mathrm{Aug}$. 2005. Contribution 2304, Atlantic Food and Horticulture Research Centre, Agriculture and Agri-Food Canada. The authors wish to thank Peter Harrison and Conny Bishop for technical assistance. This work was supported in part by a fellowship to A.A. Ramin from Isfahan University of Technology, Isfahan, Iran.

${ }^{1}$ Department of Horticulture, College of Agriculture, Isfahan University of Technology, Isfahan, Iran.

${ }^{2}$ Corresponding author; e-mail PrangeR@agr.gc.ca. ters. Antifungal activity is mainly associated with the production of isobutyric acid (IBA) 2-methyl-1-butanol (MB) and ethyl butyrate (EB) (Mercier and Jiménez, 2004). MB, IBA, and $\mathrm{EB}$ comprise $48.5 \%, 14.9 \%$, and $0.14 \%$ of the volatiles produced by fresh rye culture of $M$. albus $1 \mathrm{~h}$ after placement in a container. Other compounds produced by M. albus such as ethyl propionate, ethyl isobutyrate and methyl isobutyrate, although less inhibitory, may also contribute to the antimicrobial activity. Many of these compounds are well known as natural constituents of fresh leaves, fruit, wine, rum and blue cheese aromas, other natural essential oils and olive and vegetable oil (Federal Register, 2004).

Stinson et al. (2003) reported that sugar beet stand establishment increased and disease severity decreased in sterile soil artificially infested with Rhizoctonia solani (Kühn) AG 2-2, Verticillium dahliae Kleb. and Fusarium oxysporum Schlech.:Fr. f. sp. betae (Steward) Snyd. \& Hans after biofumigation with Muscodor albus (isolate 620) or M. roseus (isolate A3-5). They also demonstrated that eggplant seedlings grown in disease-infested soil and biofumigated with $M$. albus have significantly less disease, compared with nonbiofumigated soil. The effectiveness of $M$. albus in controlling soil-borne disease has also been reported by Mercier and Manker (2005).

In vitro exposure of a wide range of fungal and bacterial microorganisms to volatile compounds released from $M$. albus kills or inhibits spore germination and mycelial or colony growth, without physical contact, including Sclerotinia sclerotiorum, Botrytis cinerea, and Penicillium expansum, all major postharvest pathogens (Ezra and Strobel, 2003; Mercier and Jiménez, 2004; Strobel et al., 2001). Mercier and Jiménez (2004) have reported that biofumigation for $24 \mathrm{~h}$ with a culture of $M$. albus grown on autoclaved rye grain completely controls blue ( $P$. expansum) and grey mold (B. cinerea) of apple, as well as brown rot of peaches [Monilinia fructicola (Wint.) Honey], in wound-inoculated fruit. Biofumigation with $M$. albus also controls sour rot (Geotrichum citri-aurantii Butler) and green mold [P. digitatum (Pers.:Fr.) Sacc.] of lemons (Mercier and Smilanick, 2005) as well as grey mold of grapes (Mlikata Gabler et al., 2005). In the case of lemons, whole room biofumigation was attempted and shown to be successful in reducing green mold (Mercier and Smilanick, 2005).

Strobel et al. (2001) tested several of the major individual volatiles produced by $M$. albus and found that they had less effect on the growth of the tested pathogens than the M. albus culture.

The optimum amount of $M$. albus which may provide economical control of a specific microorganism without injuring stored product is not fully understood. Therefore, more research work is needed to clarify application methods and rates for $M$. albus and/or individual M. albus volatile compounds when used as biofumigants to control postharvest diseases. In this paper we investigate the in vitro biofumigation conditions needed for $M$. albus to effectively control selected major postharvest bacteria (Erwinia carotovora pv. carotovora, Pseudomonas fluorescens (isolate A7B), and Escherichia coli (K12)) and fungi (B. cinerea, P. expansum, and S. sclerotiorum). The effective anti-microbial concentrations of two major volatiles (IBA and $\mathrm{MB}$ ) and one minor volatile (EB) produced by M. albus were also investigated.

\section{Materials and Methods}

Muscodor albus and chemicals. Dry, $M$. albus strain 620-colonized rye seed (from J. Mercier, AgraQuest Inc., Davis, Calif.) was stored at $4{ }^{\circ} \mathrm{C}$ and warmed to room temperature for $2 \mathrm{~h}$ before being used in experiments. The volatile chemicals, IBA, MB, and EB were purchased from Sigma-Aldrich (Oakville, Ont., Canada).

Bacterial and fungal inoculum production. Cultures of $E$. carotovora pv. carotovora, $P$. fluorescens (A7B) and a nonpathogenic strain of $E$. coli (K12) were grown on nutrient agar (NA; Difco) for 24 to $48 \mathrm{~h}$ at $27{ }^{\circ} \mathrm{C}$ before use. Bacterial suspensions with an absorbance value of 0.05 units at $600 \mathrm{~nm}\left(\mathrm{Abs}_{600}\right)$ were prepared in $10 \mathrm{~mL}$ of sterile distilled water (SDW), then diluted 1 to 1000 before being applied to fresh NA with a spiral plater (Spiral Biotech., Bethesda, Md.).

Inhibition of S. sclerotiorum growth by $M$. albus or chemicals was tested on mycelium. Two disks of agar containing mycelium were 


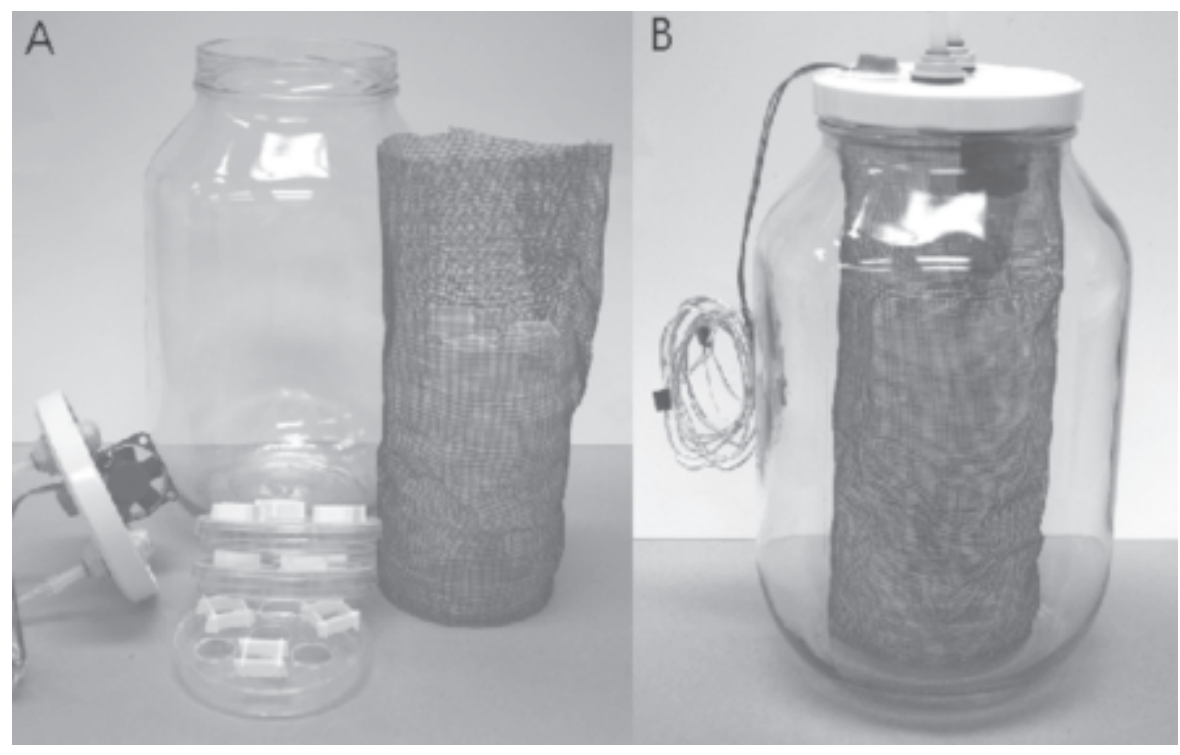

Fig. 1. The Muscodor albus and M. albus volatile treatment chamber consisting of a 4-L glass jar with a sealing lid. (A) A $4-\mathrm{cm}^{2}$ fan for air circulation was attached to the inside of the lid. Petri dishes of test microorganism spores, mycelium or cells on media were fitted with lids containing holes and spaces to facilitate air circulation. Dishes were stacked in nylon mesh sleeves to permit easy insertion and withdrawal from the chamber. (B) The assembled chamber with stacked petri dishes in the nylon sleeve.

cut with a flame sterilized corkborer from the margin of a 2-d-old colony and transferred to fresh 9-cm-diameter petri dishes of PDA and equally spaced with the mycelial side of the disk in contact with the PDA surface.

Inhibition of $P$. expansum and $B$ cinerea growth was tested on spore germination. $P$. expansum inoculum was prepared by cutting an 8-mm-diameter disk from a sporulating culture and transferring it to $10 \mathrm{~mL}$ of SDW in a $15-\mathrm{mL}$ Falcon centrifuge tube. The tube was capped tightly and shaken vigorously to dislodge and break up the chains of spores. $B$. cinerea spores were collected by flooding a sporulating culture with $10 \mathrm{~mL}$ of SDW and dislodging the spores by rubbing the culture with a bent glass rod. Spore suspension (100 $\mu \mathrm{L}$ ) was transferred with a micropipetter to the center of fresh 9-cm-diameter petri dishes of
PDA and spread over the media with a bent glass rod.

Treatment with Muscodor volatiles and $M$. albus. To assist the passage of volatiles over the surface of the media in stacks of Petri dishes the lids were ventilated with holes and separated by spacers. In a sterile laminar flow hood the lids of all the freshly inoculated Petri dishes were replaced with lids containing four, $2 \mathrm{~cm}$ diameter holes arranged in a triangle with one hole in the center. In the spaces between the holes, three 2 -cm polystyrene squares, $0.8 \mathrm{~mm}$ tall, were attached with methylene chloride (Fig. 1). Two dishes of each test microorganism were randomly stacked in a sleeve constructed of nylon fly screening $(9.7 \mathrm{~cm}$ in diameter $x$ $25 \mathrm{~cm}$ tall). Bacteria and fungi were tested separately. The sleeves of stacked dishes were lowered into 4-L glass jars with lids. To assist the distribution of volatiles within the sealed jar a 12 V DC fan (Mode Electronics, Burnaby, B.C., Canada) measuring $40 \times 40 \times 20 \mathrm{~mm}$ with a 5.2 cubic foot per min capacity was attached to the inside of each lid.

Arange of volatile chemical concentrations was used to determine the effective concentration to control each of the individual fungal and bacterial organisms tested. For EB and MB, 0 , $100,200,300$, and $400 \mu \mathrm{L}$ was added to jars containing bacterial or fungal cultures. IBA was applied at $0,50,100,150$, and $200 \mu \mathrm{L}$ per jar for fungi and $0,10,20,30$, and $40 \mu \mathrm{L}$ per jar for bacteria. The chemicals were applied to $4.25 \mathrm{~cm}$ Whatman 1 filter paper circles in $5 \mathrm{~cm}$ diameter glass Petri dishes placed on the top of the stack of cultures in the nylon sleeve within the jar. The lid was immediately screwed tight and sealed with Parafilm and the chemicals were allowed to completely volatilize. The jars were placed in a controlled environment room at $20{ }^{\circ} \mathrm{C}$. The fans were connected to a $12-\mathrm{v}$ DC power supply and the fungal and bacterial cultures were incubated in the dark for 24 and $48 \mathrm{~h}$, respectively. Similarly, to determine the weight of $M$. albus-colonized grain required to control the test fungi and bacteria, $0,1,2,3,4$, and $5 \mathrm{~g}$ of colonized grain were weighed on to 9-cm circles of Whatman 1 filter paper in the lids of 9-cm petri dishes and then placed on top of the stack of fungal or bacterial cultures in nylon sleeves within the jars. Avolume of SDW equal to the weight of the grain was added to each dish to moisten and activate the M. albus (Jiménez and Mercier 2005) plus an additional $1 \mathrm{~mL}$ to saturate the air in the jar. The control consisted of $1 \mathrm{~mL}$ of SDW without $M$. albus. The jars were immediately closed, sealed and incubated as described for the chemicals except that a second set of jars and cultures was treated with $M$. albus without fan activity.

After the prescribed incubation period the jars were returned to a vented laminar flow hood and the sleeves of cultures were removed from the jars. The dishes which contained the chemicals or M. albus were removed. After the fungal and bacterial cultures were ventilated

Table 1. Germination and growth and survival of Botrytis cinerea, Penicillium expansum, Sclerotinia sclerotiorum, Erwinia carotovora pv. carotovora, Pseudomonas fluorescens, and Escherichia coli following exposure to Muscodor albus volatiles in 4-L glass jars, with or without circulation fans (+Fan or -Fan).

\begin{tabular}{|c|c|c|c|c|c|c|c|c|c|c|c|c|}
\hline \multirow{2}{*}{$\begin{array}{l}\text { Muscodor } \\
\text { albus }^{\mathrm{z}} \\
\left(\mathrm{g} \cdot \mathrm{L}^{-1}\right)\end{array}$} & \multicolumn{2}{|c|}{$\begin{array}{l}\text { Botrytis } \\
\text { cinerea }^{\mathrm{y}}\end{array}$} & \multicolumn{2}{|c|}{$\begin{array}{l}\text { Penicillium } \\
\text { expansum }\end{array}$} & \multicolumn{2}{|c|}{$\begin{array}{c}\text { Sclerotinia } \\
\text { sclerotiorum }\end{array}$} & \multicolumn{2}{|c|}{$\begin{array}{c}\text { Erwinia carotovora } \\
\text { pv. carotovora }\end{array}$} & \multicolumn{2}{|c|}{$\begin{array}{l}\text { Pseudomonas } \\
\text { fluorescens }\end{array}$} & \multicolumn{2}{|c|}{$\begin{array}{l}\text { Escherichia } \\
\text { coli }\end{array}$} \\
\hline & - Fan & + Fan & -Fan & + Fan & -Fan & + Fan & - Fan & + Fan & -Fan & + Fan & - Fan & + Fan \\
\hline \multicolumn{13}{|c|}{ Germination or growth at removal $(\%)^{x}$} \\
\hline 0 & $100 \mathrm{a}^{\mathrm{w}}$ & $100 \mathrm{a}$ & $100 \mathrm{a}$ & $100 \mathrm{a}$ & $100 \mathrm{a}$ & $100 \mathrm{a}$ & 100 & 100 & 100 & 100 & 100 & 100 \\
\hline 0.25 & $87 \mathrm{ab}$ & $92 \mathrm{a}$ & $31 \mathrm{~b}$ & $10 \mathrm{~b}$ & $17 \mathrm{~b}$ & $17 \mathrm{~b}$ & 0 & 0 & 0 & 0 & 25 & 0 \\
\hline 0.5 & $85 \mathrm{~b}$ & $34 \mathrm{~b}$ & $5 \mathrm{c}$ & $1 \mathrm{c}$ & $14 \mathrm{bc}$ & $12 \mathrm{bc}$ & 0 & 0 & 0 & 0 & 0 & 0 \\
\hline 0.75 & $50 \mathrm{c}$ & $6 \mathrm{c}$ & $1 \mathrm{c}$ & $0 \mathrm{c}$ & $11 \mathrm{bc}$ & $5 \mathrm{~cd}$ & 0 & 0 & 0 & 0 & 0 & 0 \\
\hline 1.0 & $47 c$ & $0 \mathrm{~d}$ & $1 \mathrm{c}$ & $0 \mathrm{c}$ & $10 \mathrm{bc}$ & $3 \mathrm{~cd}$ & 0 & 0 & 0 & 0 & 0 & 0 \\
\hline 1.25 & $41 \mathrm{c}$ & $0 \mathrm{~d}$ & $0 \mathrm{c}$ & $0 \mathrm{c}$ & $8 \mathrm{c}$ & $0 \mathrm{~d}$ & 0 & 0 & 0 & 0 & 0 & 0 \\
\hline \multicolumn{13}{|c|}{ Survival after removal and $24 \mathrm{~h}$ in ambient air $(\%)$} \\
\hline 0 & 100 & 100 & 100 & 100 & 100 & 100 & 100 & 100 & 100 & 100 & 100 & 100 \\
\hline 0.25 & 0 & 0 & 31 & 0 & 100 & 0 & 0 & 0 & 0 & 0 & 25 & 0 \\
\hline 0.5 & 0 & 0 & 0 & 0 & 100 & 0 & 0 & 0 & 0 & 0 & 0 & 0 \\
\hline 0.75 & 0 & 0 & 0 & 0 & 100 & 0 & 0 & 0 & 0 & 0 & 0 & 0 \\
\hline 1.0 & 0 & 0 & 0 & 0 & 0 & 0 & 0 & 0 & 0 & 0 & 0 & 0 \\
\hline 1.25 & 0 & 0 & 0 & 0 & 0 & 0 & 0 & 0 & 0 & 0 & 0 & 0 \\
\hline
\end{tabular}

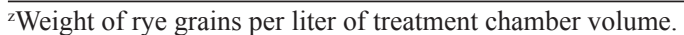

y The fungi (B. cinerea, P. expansum, and $S$. sclerotiorum) and bacteria (E. carotovora pv. carotovora, P. fluorescens, and E. coli) were exposed to M. albus volatiles for 24 and $48 \mathrm{~h}$, respectively.

${ }^{x}$ Germination or growth (\%) was assessed at removal from $M$. albus volatiles and was compared to controls. For B. cinerea and $P$. expansum, growth is defined as the germ tube length being $2 \times$ spore diameter; for $S$. sclerotiorum, growth was measured as the colony diameter. For bacteria, visible colonies were counted. ${ }^{\text {w } M e a n s ~ w i t h i n ~ a ~ c o l u m n ~ n o t ~ h a v i n g ~ t h e ~ s a m e ~ l e t t e r ~ a r e ~ s i g n i f i c a n t l y ~ d i f f e r e n t ~ a t ~} P=0.05$. 
with 2 min of compressed air to remove treatment volatiles the vented lids were replaced with standard petri dish lids. Bacterial colony numbers were estimated from counts using a spiral plate counting grid (Spiral Biotechnology, Bethesda, Md.) and the per cent colony survival compared with the controls was calculated. Sclerotinia sclerotiorum growth was quantified by taking two measurements, perpendicular to each other, of the diameter of mycelial growth from each of the two mycelial disks applied to each dish of media and a percent growth relative to the control was calculated. The percent spore germination was recorded for $P$. expansum and $B$. cinerea cultures by counting 100 spores near the center of the petri dish and recording the number of spores with germ tubes $2 \times$ longer than the width of the spore. All counts were made immediately after the end of the treatment period and again after an additional $24 \mathrm{~h}$ of incubation on a lab bench. All experiments were repeated three times.

Statistical analysis. For each organism, the five levels of M. albus (fixed factor 1) were randomly assigned to chambers with or without a circulation fan (fixed factor 2) in a two-way randomized complete design structure. Where the data were normally distributed, the germination, growth or survival means $(n=6)$ for each organism treated with or without a fan at each level of M. albus were separated by the Waller Duncan k ratio $t$ test, where $\mathrm{k}=100$ approximates $P=0.05$, of SAS's Proc GLM (SAS Institute, 1994). The relationship between the dependent variables, fungal spore germination or mycelial growth, or bacterial colony establishment (Y), and the levels of the independent variables, IBA, $\mathrm{MB}$, or EB (X), was established by logistic regression (SigmaPlot, 2004). Unless noted otherwise, only results significant at $P=0.05$ are discussed.

\section{Results}

Muscodor albus volatiles had a significant effect on the germination, growth and survival of the three postharvest fungi ( $B$. cinerea, $P$. expansum, and $S$. sclerotiorum) and bacteria (E. carotovora pv. carotovora, P. fluorescens $\mathrm{A} 7 \mathrm{~B}$, and E. coli $\mathrm{K} 12$ ) examined in this study (Table 1). The fungal results clearly show that increasing the weight of $M$. albus-colonized grain from 0.25 to $1.25 \mathrm{~g} \cdot \mathrm{L}^{-1}$ had a significant effect $(P=0.05)$ on the ability of $M$. albus volatiles to inhibit spore germination of $B$. cinerea and $P$. expansum and colony diameter increase of $S$. sclerotiorum. While spore germination of $P$. expansum and colony growth of $S$. sclerotiorum were nearly completely inhibited in the presence of $1.25 \mathrm{~g} \cdot \mathrm{L}^{-1}$ of M. albus-colonized grain, B. cinerea in jars without air circulation (-Fan) had $41 \%$ of the spores germinated after $24 \mathrm{~h}$. However, $B$. cinerea spores in jars with air circulation fans (+Fan) stopped germinating at $1.0 \mathrm{~g} \cdot \mathrm{L}^{-1}$ of $M$. albus-colonized grain. This difference between the efficacy of M. albus volatiles with and without air circulation was not evident with P. expansum or S. sclerotiorum.
The results of the fungal spore and mycelium survival or growth $24 \mathrm{~h}$ after removal from the treatments and placement in ambient air are markedly different than the germination and growth results measured immediately after removal. None of the germinated spores or mycelial colonies exposed to M. albus volatiles continued to grow except for $P$. expansum at $0.25 \mathrm{~g} \cdot \mathrm{L}^{-1}$ without air circulation (-Fan) and S. sclerotiorum at 0.25 to $1.0 \mathrm{~g} \cdot \mathrm{L}^{-1}$ (-Fan) (Table 1).

All three of the test bacteria were killed or suppressed after a $48 \mathrm{~h}$ exposure to M. albus volatiles even at the lowest weight of colonized rye grain except for $E$. coli (Table 1). Of the E. coli colonies, $25 \%$ at $0.25 \mathrm{~g} \cdot \mathrm{L}^{-1}$ without air circulation (-Fan) survived the M. albus volatiles but none survived or grew after the same exposure with air circulation (+Fan).

The three test volatiles, MB, IBA, and EB, had an inhibitory effect on one or more of the six test organisms, as measured immediately after removal from treatment (data not shown) and again 24 h later (Figs. 2, 3, and 4, respectively). Preliminary research showed that, without fan-assisted circulation of the volatiles, their inhibitory effects were restricted to culture surfaces immediately below the openings in
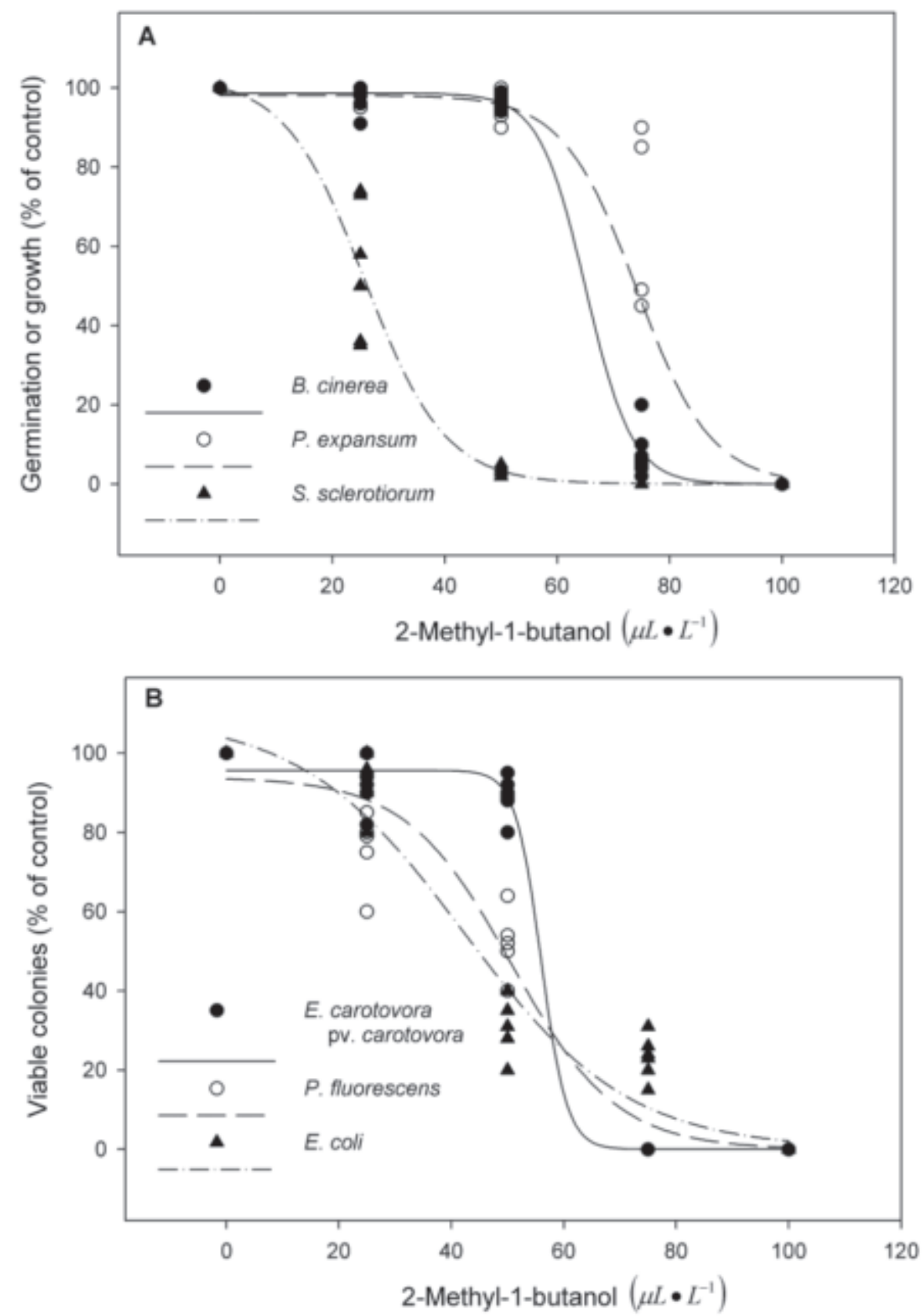

Fig. 2. Influence of 2-methyl-1-butanol (MB) after $24 \mathrm{~h}$ postremoval on (A) germination (\%) of Botrytis cinerea [germination $\left.(\%)=98.7 /(1+\exp (-(\mathrm{x}-65.1) /-4.1)), R^{2}=0.99\right]$, Penicillium expansum [germination $\left.(\%)=98.1 /(1+\exp (-(x-74.2) /-6.6)), R^{2}=0.96\right]$, and Sclerotinia sclerotiorum [mycelial growth $\left.(\%)=102.6 /(1+\exp (-(\mathrm{x}-25.8) /-7.1)), R^{2}=0.98\right]$ or $(\mathrm{B})$ viable colonies $(\%)$ of Erwinia carotovora $\mathrm{pv}$. carotovora $\left[\right.$ viable colonies $(\%)=95.7 /(1+\exp (-(\mathrm{x}-56) /-2.3)), R^{2}=0.99$ ], Pseudomonas fluorescens [viable colonies $(\%)=93.9 /(1+\exp (-(\mathrm{x}-50.6) /-9.3)), R^{2}=0.98$ ], and Escherichia coli [viable colonies $\left.(\%)=109.4 /(1+\exp (-(\mathrm{x}-42.3) /-14.6)), R^{2}=0.98\right]$. 
the petri dish lids (Fig. 5). Thus, only data generated from chambers with fan circulated atmospheres are presented and discussed. For the three fungi treated with $\mathrm{MB}$, there was no germination (B. cinerea and P. expansum) and no growth (S. sclerotiorum) at $100 \mu \mathrm{L} \cdot \mathrm{L}^{-1}$ (Fig. 2a). The $50 \%$ inhibitory concentration $\left(\mathrm{IC}_{50}\right)$ for germination or growth was 27, 65, and $75 \mu \mathrm{L} \cdot \mathrm{L}^{-1}$ for $S$. sclerotiorum, B. cinerea, and $P$. expansum, respectively. The slopes of the linear portion of the regression lines were similar for the three fungi $(-3.8,-3.5$, and -5.5 , respectively). Erwinia carotovora pv. carotovora was killed or suppressed at $75 \mu \mathrm{L} \cdot \mathrm{L}^{-1}$ of $\mathrm{MB}$ and there was no growth of P. fluorescens or E. coli at $100 \mu \mathrm{L} \cdot \mathrm{L}^{-1}$ of MB (Fig. 2b). The $\mathrm{IC}_{50} \mathrm{~s}$ for P. fluorescens, E. coli and $E$. carotovora pv. carotovora were 50 , 45 and $56 \mu \mathrm{L} \cdot \mathrm{L}^{-1}$, respectively. The slopes of the regression lines for $P$. fluorescens and $E$. coli were -2.3 and -1.8 , respectively, but $E$. carotovora pv. carotovora was steeper with a slope of-8.6 indicating that the latter pathogen was markedly more sensitive to MB over the concentration range tested.

When IBA was used, all three fungi were reduced to $0 \%$ germination or growth at $<45$ $\mu \mathrm{L} \cdot \mathrm{L}^{-1}$ (Fig. 3a). Botrytis cinerea $\left(\mathrm{IC}_{50}=10\right)$ and $S$. sclerotiorum $\left(\mathrm{IC}_{50}=8\right)$ appeared to be more sensitive than $P$. expansum $\left(\mathrm{IC}_{50}=38\right)$, however, the slopes of the linear portions of the regression lines were much steeper for $B$. cinerea $(-23)$ and $P$. expansum $(-30)$ than for S. sclerotiorum (-5.5). All three bacteria were more sensitive to IBA than the three fungi (Fig. 3b). The $\mathrm{IC}_{50}$ for P. fluorescens, E. coli, and $E$. carotovora pv. carotovora were $2.3,2.9$, and $3.1 \mu \mathrm{L} \cdot \mathrm{L}^{-1}$, respectively. In this instance the slope of the linear portion of the regression curve was much steeper for E.coli (-200) than for $P$. fluorescens $(-15)$ and E. carotovora $\mathrm{pv}$. carotovora $(-16.7)$.

Fumigation with EB at $100 \mu \mathrm{L} \cdot \mathrm{L}^{-1}$ did not affect any of the six organisms (data not shown), except for S. sclerotiorum (Fig. 4). There was no mycelial growth of $S$. sclerotiorum at 100 $\mu \mathrm{L} \cdot \mathrm{L}^{-1}$ and the $\mathrm{IC}_{50}$ value was $35 \mu \mathrm{L} \cdot \mathrm{L}^{-1}$ with a regression curve slope of -1.7 .

\section{Discussion}

Muscodor albus volatiles show great potential for controlling important postharvest diseases both in vitro and in vivo. All bacterial and fungal postharvest organisms tested were killed or suppressed by $M$. albus under the conditions defined in this study (Table 1). The bacteria seemed to be more sensitive than the fungi to the M. albus volatiles; however, they were exposed to the volatiles for $48 \mathrm{~h}$ while the fungi could only be exposed for $24 \mathrm{~h}$. The rapid mycelial growth of the fungi threatened to overgrow the media making it impossible to count germinated spores or measure radial growth at sublethal exposures of $>24 \mathrm{~h}$. While there was considerable germination of $B$. cinerea and mycelial growth of $S$. sclerotiorum even at $1 \mathrm{~g} \cdot \mathrm{L}^{-1}$ of $M$. albus-colonized grain, these spores and mycelia were shown to be dead or exhibited inhibited growth in most treatments $24 \mathrm{~h}$ postremoval, even at the lowest weight of
M. albus (Table 1). This discrepancy between effects of volatiles on germination and survival is likely related to the relative rates of spore germination and production of volatiles by $M$. albus. Muscodor albus is preserved as an airdried mycelium on grains and is activated at the start of the experiment with an application of an equal weight of water(Jiménez and Mercier, 2005). Once hydrated, M. albus will produce maximum concentrations of volatiles within 24 h (Mercier and Jiménez, 2005), similar to fresh culture recently placed in a closed container (Mercier and Jiménez, 2004). Botrytis cinerea germinated in 3 to $4 \mathrm{~h}$ at $20{ }^{\circ} \mathrm{C}$ (data not shown) and S. sclerotiorum can completely colonize a $10 \mathrm{~cm}$ petri dish in just $72 \mathrm{~h}$. Therefore, lethal concentrations of the volatiles may not be reached in the treatment chamber until after spore germination or mycelial growth has been initiated. In addition, it can be seen that spore germination of $B$. cinerea or survival of S. sclerotiorum mycelium without fan-assisted air circulation was greater. None of the six microorganisms survived even the lowest amount of M. albus in jars with air circulation after 24 $\mathrm{h}$ postremoval, and $B$. cinerea germination was reduced. The increased efficacy of $M$. albus volatiles in response to air circulation was
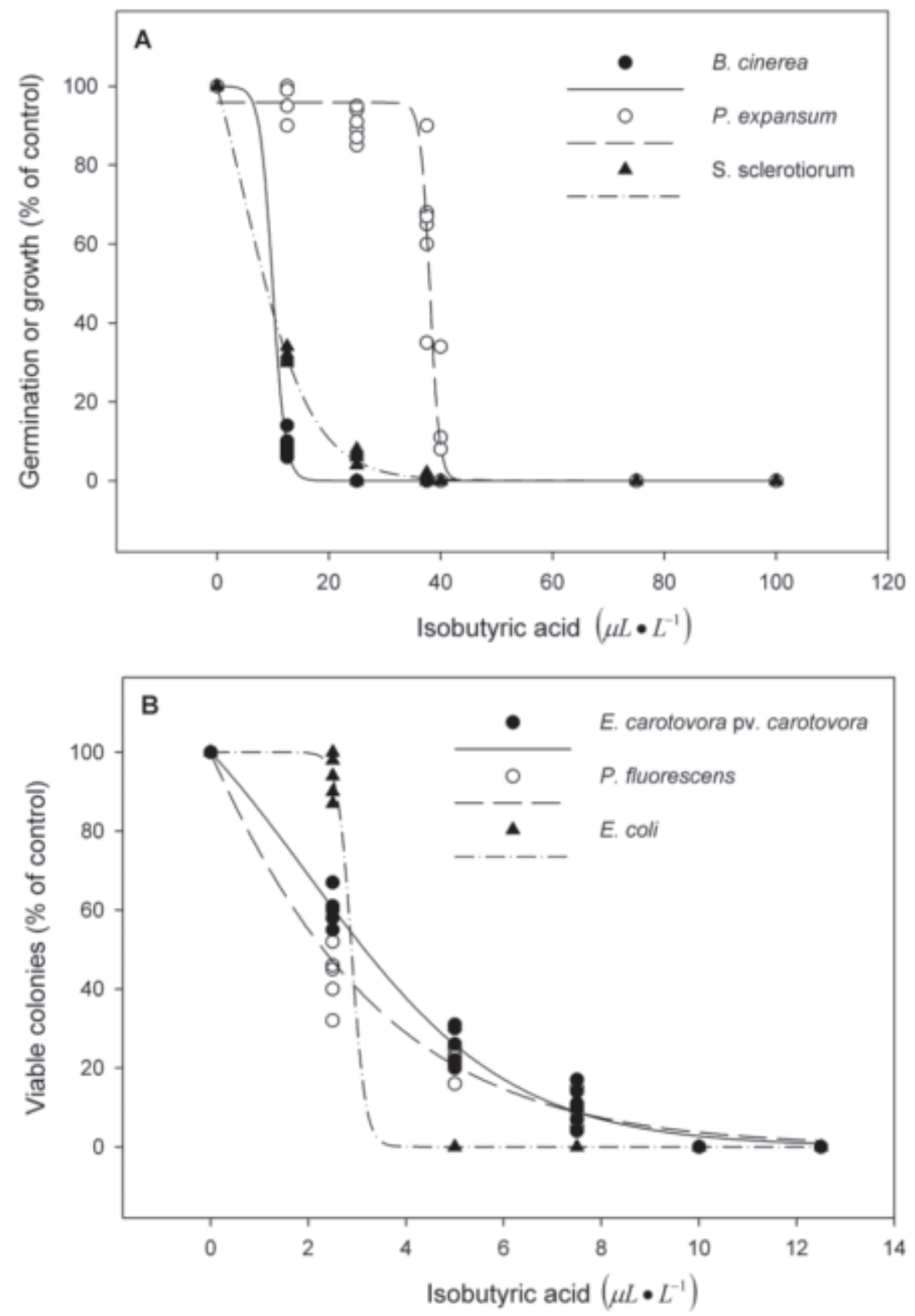

Fig. 3. Influence of isobutyric acid (IBA) after $24 \mathrm{~h}$ postremoval on (A) germination (\%) of Botrytis cinerea [germination $(\%)=100 / 91+\exp (-(\mathrm{x}-9.9) /-1.1)), R^{2}=0.99$ ], Penicillium expansum [germination $\left.(\%)=95.8 /(1+\exp (-(\mathrm{x}-38.1) /-0.8)), R^{2}=0.99\right]$, and Sclerotinia sclerotiorum [mycelial growth $\left.(\%)=145.8 /(1+\exp (-(\mathrm{x}-4.7) /-6.0)), R^{2}=0.99\right]$ or $(\mathbf{B})$ viable colonies $(\%)$ of Erwinia carotovora pv. carotovora $\left[\right.$ viable colonies $\left.(\%)=137.5 /(1+\exp (-(\mathrm{x}-2.0) /-2.1)), R^{2}=0.99\right]$, Pseudomonas fluorescens [viable colonies $(\%)=469.2 /(1+\exp (-(\mathrm{x}+3.69) /-2.8)), R^{2}=0.99$ ], and Escherichia coli [viable colonies $(\%)=100 /(1+\exp (-(\mathrm{x}-2.88) /-0.14)), R^{2}=0.99$ ] 
likely the result of heavier-than-air volatiles settling to the bottom of the containers if not stirred. Also, the petri dishes of microorganisms were stacked inside nylon mesh sleeves with only a few holes in the lids of the dishes, which may have restricted air movement over the surface of the media. This was particularly evident when $P$. fluorescens was exposed to IBA $\left(7.5 \mu \mathrm{L} \cdot \mathrm{L}^{-1}\right)$ without fan-circulated air and colony inhibition only occurred directly below the holes in the lid (Fig. 5). Similar, but less dramatic, results were observed for all the fungal and bacterial organisms tested. Therefore, circulation of the volatiles appears to be required to maximize efficacy and will likely be important in biofumigation of bulkstored fruits and vegetables.

Previously, it had been established that the main volatile compounds responsible for the inhibitory activity of $M$. albus against microorganisms were esters, alcohols and acids (Ezra et al., 2004; Strobel et al., 2001). In several studies, artificial combinations of a few to 20 of the identified volatiles have been tested for antimicrobial activity comparable to M. albus (Ezra et al., 2004; Ezra and Strobel, 2003; Strobel et al., 2001). Mercier and Jiménez (2004) determined that IBA, $\mathrm{MB}$, and $\mathrm{EB}$ had the greatest antimicrobial activity; however, the conditions, methods of application and the optimum rates were not published. In our work, IBA had greater antimicrobial activity than MB, and EB had little activity except against $S$. sclerotiorum. While all fungi and bacteria were killed or suppressed by exposure to $<45$ and $<12.5$ $\mu \mathrm{L} \cdot \mathrm{L}^{-1}$ of IBA and $\mathrm{MB}$, respectively, these calculated concentrations were considerably higher than the 4.6 and $15.5 \mathrm{~nL} \cdot \mathrm{L}^{-1}$ measured in the headspace above $M$. albus cultures (Mercier and Jiménez, 2004). Discrepancies in the response to individual M. albus volatiles compared with the natural suite of volatiles produced by $M$. albus cultures has been attributed to synergistic activity. However, Strobel et al. (2001) report that the optimum concentration of an artificial mixture of $M$. albus volatiles giving comparable inhibitory and biocidal effects was $1200 \mu \mathrm{L} \cdot \mathrm{L}^{-1}$, which is higher than the individual volatile activities demonstrated in this study. This fact does not support a theory of synergistic activity and suggests that other unidentified volatiles may be involved. While the fungi or bacteria in this study had similar $\mathrm{IC}_{50}$ values for individual chemicals, some had very different regression line slopes. Botrytis cinerea, $P$. expansum, and $E$. coli had steeper slopes of their $\mathrm{IC}_{50}$ regression curves than the other test microorganisms (Fig. 3). These very sensitive reactions to the individual volatiles around the organisms' IC $_{50}$ values made it impossible to determine if combinations of chemicals were synergistic, since the Abbott technique for measuring synergism examines the effect on growth or survival of the organism for the combination of two chemicals at their $\mathrm{IC}_{50}$ values compared with the individual chemical response (Gisi, 1996). Just the slightest variance in volatile chemical application resulted in missing the $\mathrm{IC}_{50}$ and rendering

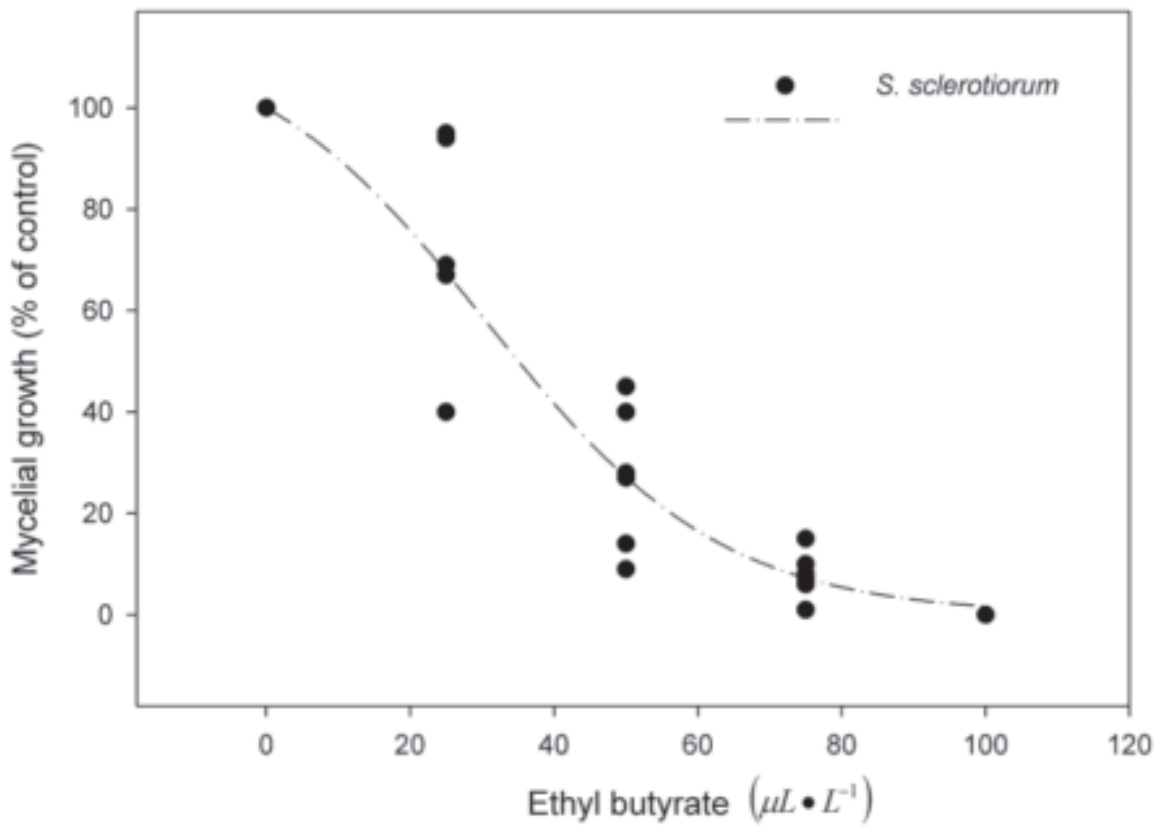

Fig. 4. Influence of ethyl butyrate (EB) after $24 \mathrm{~h}$ postremoval on square root mycelial growth (\%) of Sclerotinia sclerotiorum [mycelial growth $(\%)=115.3 /(1+\exp (-(\mathrm{x}-30.7) /-16.4)), R^{2}=0.96$ ]

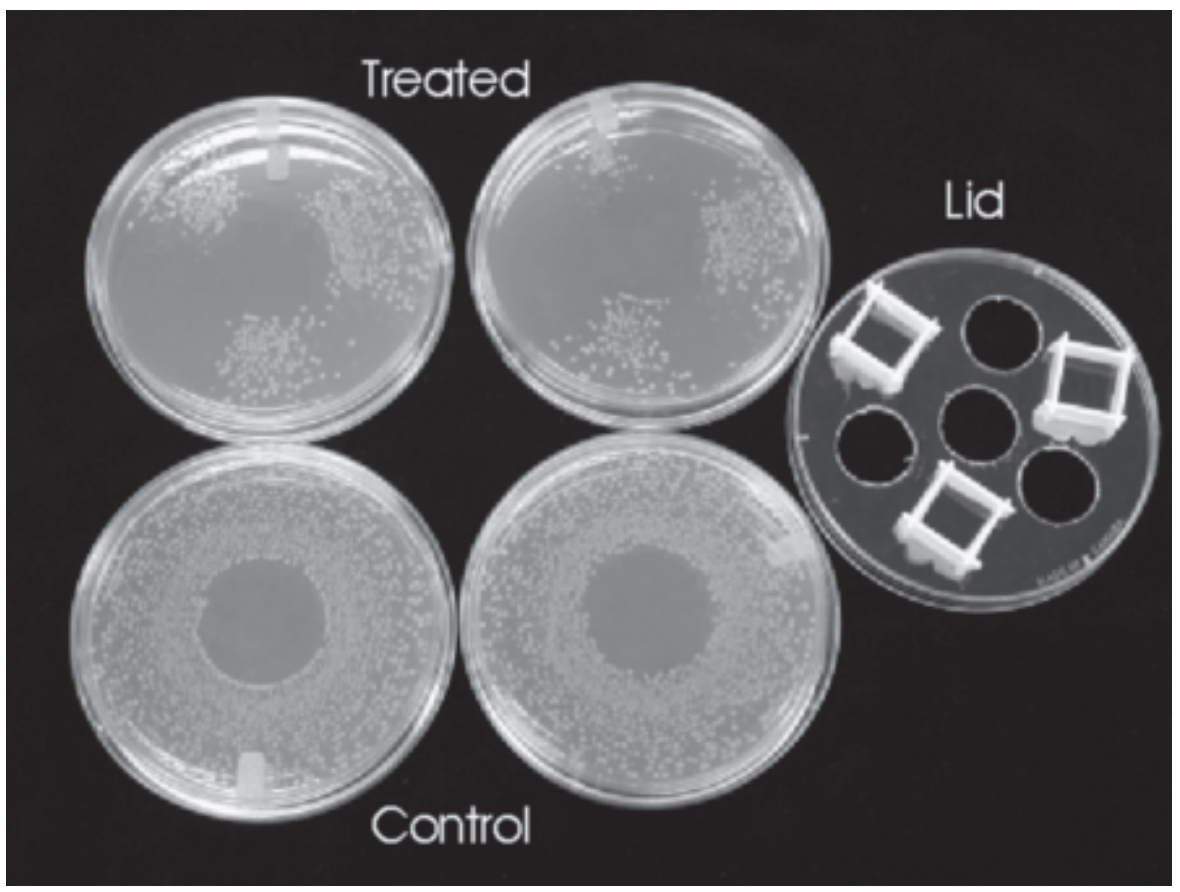

Fig. 5. Effects of isobutyric acid $\left(7.5 \mu \mathrm{L} \cdot \mathrm{L}^{-1}\right)$ in jars without fan-circulated air on colony growth of Pseudomonas fluorescens below holes in the petri dish lids. The control petri dish received no treatment.

the results out of range and not suitable for analysis (data not shown).

Recently, Muscodor spp. have been tested for use in certain agricultural settings to treat pathogen-infested plants, soil and seeds, with promising results (Mercier and Jiménez, 2004; Mercier and Manker, 2005; Mercier and Smilanick, 2005; Stinson et al., 2003; Strobel et al., 2001). Previous experiments indicated 1 to $13 \mathrm{~g} \cdot \mathrm{L}^{-1}$ of $M$. albus-colonized grain controlled blue and grey mold of apple (Mercier and Jimenez, 2004). However, our finding that only $0.25 \mathrm{~g} \cdot \mathrm{L}^{-1}$ with atmosphere circulation was adequate to control fungal and bacterial pathogens in vitro suggests that using lower quantities of $M$. albus-colonized grain may be feasible. In addition, more results will have to be obtained in vivo, as interaction with stored products and accessibility of the volatiles to infection sites might affect their efficacy.

\section{Literature Cited}

Adaskaveg,J.E., H. Förester, and N.F. Sommer. 2002. Principles of postharvest pathology and management of decays of edible horticultural crops, p. 163-195. In: A.A. Kader (ed.). Postharvest technology of horticultural crops. 3rd ed. Univ. 
Calif. Agr. Natural Resources Publ. 3311.

Eckert, J.W. and J.M. Ogawa. 1988. The chemical control of postharvest diseases: Deciduous fruit, berries, vegetables and root/tuber crops. Annu. Rev. Phytopathol. 26:433-460.

Ezra, D., W.M. Hess, and G.A. Strobel. 2004a. New endophytic isolates of Muscodor albus, a volatile-antibiotic-producing fungus. Microbiology 150:4023-4031.

Ezra, D., J. Jasper, T. Rogers, B. Kinghton, E. Grimsrud, and G. Strobel. 2004b. Proton transfer reaction-mass spectrometry as a technique to measure volatile emissions of Muscodor albus. Plant Sci. 166:1471-1477.

Ezra, D. and G.A. Strobel. 2003. Effect of substrate on the bioactivity of volatile antimicrobials produced by Muscodor albus. Plant Sci. 165:1229-1238.

Federal Register. 2004. Muscodor albus strain QST 20799; notice of filing a pesticide petition to establish an exemption from tolerance for a certain pesticide in or on food. Fed. Reg. 69(67):1-16.
Gisi, U. 1996. Synergistic interaction of fungicides in mixtures. Phytopathology 86:1273-1279.

Jiménez, J.I. and J. Mercier. 2005. Optimization of volatile organic compound production from rye grain culture of Muscodor albus for postharvest fumigation. Amer. Phytopathol. Soc. Annu. Mtg. (abstr.).

Mercier, J. and J.I. Jiménez. 2004. Control of fungal decay of apples and peaches by the biofumigation fungus Muscodor albus. Postharvest Biol. Technol. 31:1-8.

Mercier, J. and D.C. Manker. 2005. Biocontrol of soil-borne diseases and plant growth enhancement in greenhouse soilless mix by the volatileproducing fungus Muscodor albus. Crop Prot. 24:355-362.

Mercier, J. and J.L. Smilanick. 2005 . Control of green mold and sour rot of stored lemon by biofumigation with Muscodor albus. Biol. Control 32:401-407.

Mlikota Gabler, F., R. Fassel, J. Mercier and J.L. Smilanick. 2005. Influence of packaging, tem- perature, and inoculation timing on the effectiveness of biofumigation with Muscodor albus to control postharvest gray mold on table grapes. Amer. Phytopathol. Soc. Annu. Mtg. (abstr.).

SAS Institute. 1994. SAS/STAT user's guide. vol 1-2. version 6. 4th ed. SAS Inst., Cary, N.C.

SigmaPlot. 2004. SigmaPlot 2004 Windows Version 9. Systat Software Inc., Point Richmond, Calif.

Stinson, A.M., N.K. Zidack, G.A. Strobel, and B.J. Jacobsen. 2003. Mycofumigation with Muscodor albus and Muscodor roseus for control of seedling diseases of sugar beet and Verticillium wilt of eggplant. Plant Dis. 87:1349-1354.

Strobel, G.A., E. Drike, J. Sears, and C. Markworth. 2001. Volatile antimicrobials from Muscodor albus, a novel endophytic fungus. Microbiology 147:2943-2950.

Worapong, J., G. A. Strobel, E.J. Ford, J.Y. Li, G. Baird, and W.M. Hess. 2001. Muscodor albus anam. gen. et sp. nov., an endophyte from Cinnamomum zeylanicum. Mycotaxon 79:67-79. 